\title{
INVESTIGATION OF STRUCTURE OF VARIOUS SURFACE \\ KARST FORMATIONS IN LIMESTONE AND DOLOMITE BEDROCK WITH APPLICATION OF THE ELECTRICAL RESISTIVITY IMAGING
}

\section{PROUČEVANJE ZGRADBE RAZLIČNIH KRAŠKIH OBLIK V APNENCIH IN DOLOMITIH Z UPORABO METODE ELEKTRIČNE UPORNOSTI TAL}

\author{
Uroš STEPIŠNIK ${ }^{1}$, Andrej MIHEVC ${ }^{2}$
}

\begin{abstract}
Abstact
UDC 551.435:552.54:537.31

Uroš Stepišnik, Andrej Mihevc: Investigation of structure of various surface karst formations in limestone and dolomite bedrock with application of the Electrical resistivity imaging Karst landforms are developed in different kind of rocks and in different structural settings. Authors are presenting some results of profile measurement of Electrical resistivity imaging in some dolines and collapse dolines that developed in limestone and dolomite in Slovenia. Selected features are examples of surface karst landforms which could be morphologically defined as typical of its kind. For electrical resistivity imaging data collection was used SuperSting R1/IP earth resistivity meter. Electrical resistivity imaging method was applied for research of material characteristics beneath surface of karst landforms. Materials with higher portion of water as fractured bedrock or clay are less resistant to electrical current than unfractured bedrock. Application of the ERI method has turned out as appropriate for detailed investigation of surface karst landforms. Keywords: electrical resistivity imaging, ERI, karst, geomorphology, epikarst, doline, collapse doline.
\end{abstract}

Izvleček

UDK 551.435:552.54:537.31

Uroš Stepišnik, Andrej Mihevc: Proučevanje zgradbe različnih kraških oblik $v$ apnencih in dolomitih $z$ uporabo metode električne upornosti tal

Površinske kraške oblike so razvite $\mathrm{v}$ različnih vrstah kamnine in imajo različno zgradbo. Avtorja predstavljata rezultate meritev profilov električne upornosti tal vrtač in udornic v Sloveniji, ki se nahajajo $\mathrm{v}$ apnencih in dolomitih. Izbrane oblike so primeri površinskih kraških oblik, ki jih je mogoče morfološko opredeliti kot tipične. Za meritve električne upornosti tal je bil uporabljen merilec električne upornosti SuperSting R1/IP. Metoda električne metode je bila uporabljena za ugotavljanje lastnosti materiala pod površjem $\mathrm{v}$ površinskih kraških oblikah. Materiali z večjim deležem vode, kot so pretrta kamnina ali ilovica, imajo manjšo električno upornost kot nepretrta kamnina. Uporaba metode električne upornosti tal se je izkazala kot primerna za podrobno proučevanje površinskih kraških oblik. Ključne besede: električna upornost tal, kras, geomorfologija, epikras, vrtače, udornice.

\section{INTRODUCTION}

Karst surface in Slovenia covers area about $44 \%$ or 9000 $\mathrm{km}^{2}$ (Novak, 1993). It developed mainly in limestone and dolomite bedrock. Dolomite covers the area of $12 \%$ or $2500 \mathrm{~km}^{2}$ (Gabrovec, 1994) and karst in limestone covers the area about $32 \%$ or $6500 \mathrm{~km}^{2}$. Some of the karst landforms developed both on dolomite and limestone and are covered with soil or detritic material. Different chemical and mechanical composition of limestone and dolomite results in different processes and different dynamics of processes on them. The morphology of karst surface and structure of the subsurface is essential for understanding of processes on karst. It is possible to image the subsurface quickly and inexpensively through the application of various nonintrusive surface geophysical methods.

This paper presents results of Electrical resistivity imaging in some dolines and collapse dolines in limestone and dolomite on Slovenian karst and interpretation of data. Selected karst landforms are examples of surface

\footnotetext{
${ }^{1}$ University of Ljubljana, Department of Geography, Aškerčeva 2, SI-1000 Ljubljana, Slovenia

${ }^{2}$ Karst research institute ZRC SAZU, Titov trg 2, SI-6230 Postojna, Slovenia
}

Received/Prejeto: 30.01 .2008 
karst landforms which could be morphologically defined as typical of its kind. Subsurface structures of various dolines were revealed through construction works on karst which corresponds to the data obtained with method of electrical conductivity imaging. On the other hand we have no data about subsurface structures of collapse dolines, so subsurface data of dolines were used to interpret subsurface data of collapse dolines revealed through application of electrical resistivity imaging. The method turned out as appropriate for a robust visualization of epikarst structure and subsurface structure of karst features.

\section{METHODS OF ELECTRICAL RESISTIVITY}

Electrical resistivity imaging has been successfully utilized for characterizing the subsurface for many years but it has certain limitations. The method was labour intensive, interpretation of data was time intensive and the method based on individual subjective interpretation (Roman, 1951; Zhou et al. 2002).

Development of computer controlled multi electrode resistivity survey systems and the development of resistivity modelling software (Locke \& Barker, 1996) have allowed more cost effective resistivity surveys and better interpretation of the subsurface. These surveys are usually referred as Electrical resistivity imaging (ERI) or Electrical resistivity tomography (ERT) (Zhou et al., 2002). These facts allow data to be collected and processed quickly so the electrical resistivity imaging surveys become a valuable tool in subsurface investigations (Zhou et al. 2000).

Electrical resistivity imaging surveys are typically conducted to determine the resistivity of the subsurface. Resistivity data can be used to determine the location of various geologic and soil strata, bedrock fractures, faults and voids. Fundamental to all resistivity methods is the concept that current is impressed into the ground and the effect of this current within the ground can be measured. The effect of potential or differences of potential, ratio of potential differences, or some other parameter that is directly related to these variables are the most commonly measured effect of the impressed current. The principal differences among various methods of Electrical resistiv- ity lie in number and spacing of the current and potential electrodes the variable quantity determined and the manner of presenting the results (Earthimager 2003).

Carbonate rock in general has a significantly higher resistivity than clayey soil because it has much smaller primary porosity and fewer interconnected pore spaces. Its resistivity value is about $1000 \mathrm{ohm}-\mathrm{m}$ (Telford et al. 1990). Clayey materials can hold more moisture and have higher concentration of ion to conduct electricity, therefore, have resistivity values less than $100 \mathrm{ohm}-\mathrm{m}$ (Telford et al. 1990). The high contrast in resistivity values between carbonate rock and clayey material favours the use of Electrical resistivity method for determine the boundary between bedrock and overburden (Zhou et al. 2000).

A frequently occurring problem with Earth resistivity imaging is to determine which electrode configuration will respond best to the material changes in karst features. Each array has distinctive advantages and disadvantages in terms of sensitivity to the material variations, depth of investigation and signal strength. The most typical arrays are dipole-dipole array, Wenner array and Schlumberger array. The dipole-dipole array gives good horizontal resolution of data while Wenner and Schlumberger arrays are more directed in vertical resolution. In application on karst surveys the dipole-dipole array provided highest precision of ground changes sensitivity and has greatest sensitivity to vertical resistivity boundaries (Zhou et al. 2002).

\section{STUDY AREAS AND INTERPRETATION OF DATA}

Electrical resistivity data were collected in four different sites. Those sites include two collapse dolines and two dolines. One collapse doline and one doline are situated in limestone while the other two are situated in dolomite. Selected karst landforms are typical examples of surface karst landforms which occur on karst in Slovenia.
The SuperSting R1/IP earth resistivity meter developed by Advanced Geosciences, Inc. was used for data collection. Survey was conducted with dipole-dipole array. The distance between two electrode pairs was between 3 and $5 \mathrm{~m}$. The data was processed to generate two-dimensional resistivity models using EarthImager $2 \mathrm{D}$ resistivity inversion software developed by Advanced 


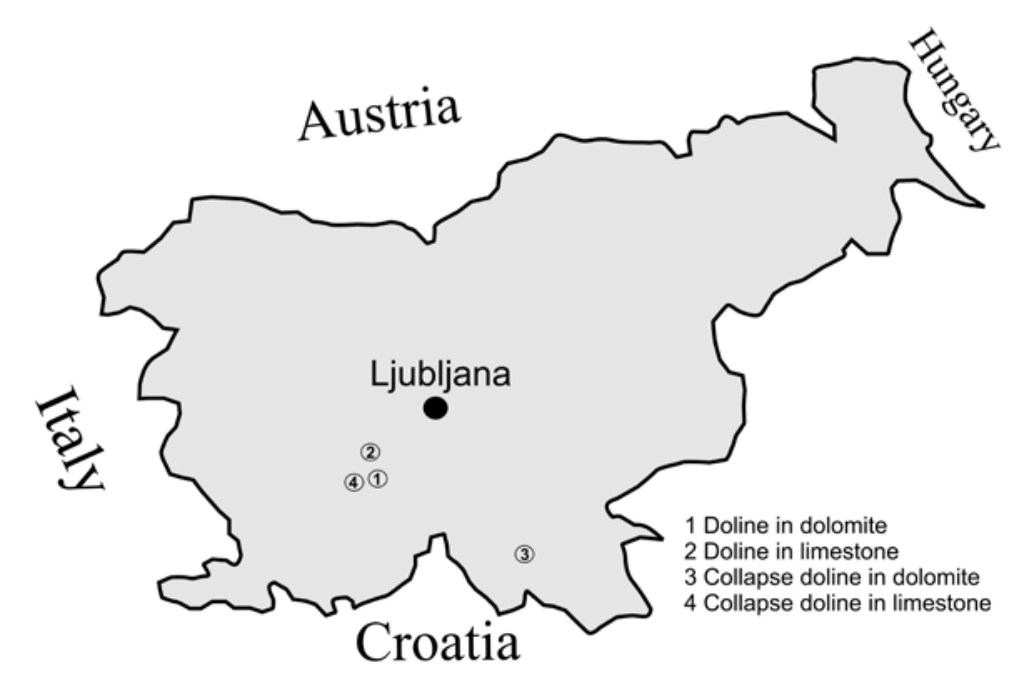

Fig. 1: Location of the investigated sites.

Geosciences, Inc. The Root-Mean-Square (RMS) error quantifies the difference between the measured resistivity values and those calculated from the true resistivity model. A small RMS error value indicates small differences. The minimum RMS error in the survey was $2.72 \%$; the maximum error was $5.8 \%$.

The reliable data of two-dimensional resistivity images decrease in lateral extent towards greater depth. This means that all data in the rectangular raster images (Figs. 2,4,6,8) are not relevant. Only data in trapezoidal shape is valid, not outer lower sections of the rectangular images.

\section{DOLINE IN DOLOMITE IN BEGUNJSKI RAVNIK AREA}

Begunjski ravnik is levelled karst area north of Cerkniško polje in central Slovenia. On southern and eastern part of the area is Triassic and Jurassic dolomite with dip of beds from 15 to 20 degrees towards west. It changes to Jurassic limestone towards west (Buser 1963). Hydrologically the area is still mainly unexplored. There are no caves with access to epiphreatic or phreatic zone, which is presumably $40 \mathrm{~m}$ below the surface. Presumably the underground flow is in area directed from the stream Cerkniščica and Cerkniško polje towards north to springs of the Ljubljanica near Vrhnika.

The doline is positioned in lower Jurassic grey sparry dolomite 2 kilometres northeast of Begunje in the flat karst area densely covered by dolines. The doline has longer diameter $35 \mathrm{~m}$, shorter diameter $20 \mathrm{~m}$ and depth 7 $\mathrm{m}$, approximate volume of the doline is $1100 \mathrm{~m}^{3}$. The slopes are covered with rocky soil. Dip of the slopes of the doline 40 degrees with highest dip on western slope with 50 degrees. The floor of the doline is flat and covered with clayey soil.

Results of Electrical resistivity imaging profile through the doline with distance between two electrode pairs 3 metres show that under a thin layer of less resistant clayey soil and weathered rock on the slopes of the doline with resistivity value up to $1000 \mathrm{ohm}$-m there is more resistant dolomite bedrock with resistivity values higher than $1000 \mathrm{ohm}-\mathrm{m}$. The floor of the doline is filled with 10 metres thick layer of clayey soil with resistivity value up to $250 \mathrm{ohm}-\mathrm{m}$, overlaying unfractured dolomite bedrock. Under the deepest eastern part of the doline floor is a less resistant vertical structure with resistivity value up to $250 \mathrm{ohm}-\mathrm{m}$ which might be fault or vertical karst void filled with weathered bedrock or clayey material.

\section{DOLINE IN LIMESTONE IN LOGAŠKI RAVNIK AREA}

Logaški ravnik is a relatively flat karst area north west of Begunjski ravnik and north east of Planinsko polje. Bedrock is mainly lower Cretaceous limestone with beds of dolomites with dip of beds about 20 degrees toward west. (Pleničar et al. 1963).

Underground waters flow from the area of Cerkniško polje and Planinsko polje to north towards the area of the Ljubljanica River springs near Vrhnika. According to Habič (1985) piezometric level in the area is at the on altitude between 350 and 400 metres. Recent explorations revealed that in the area piezometric level is on altitude 420 metres being about 100 metres below the surface of Logaški ravnik (Kataster jam JZS 2006).
Fig. 2: ERI profile of the doline in dolomite in Begunjski ravnik area (ERI profile direction 88 degrees; RMS error $3.6 \%$ ). 


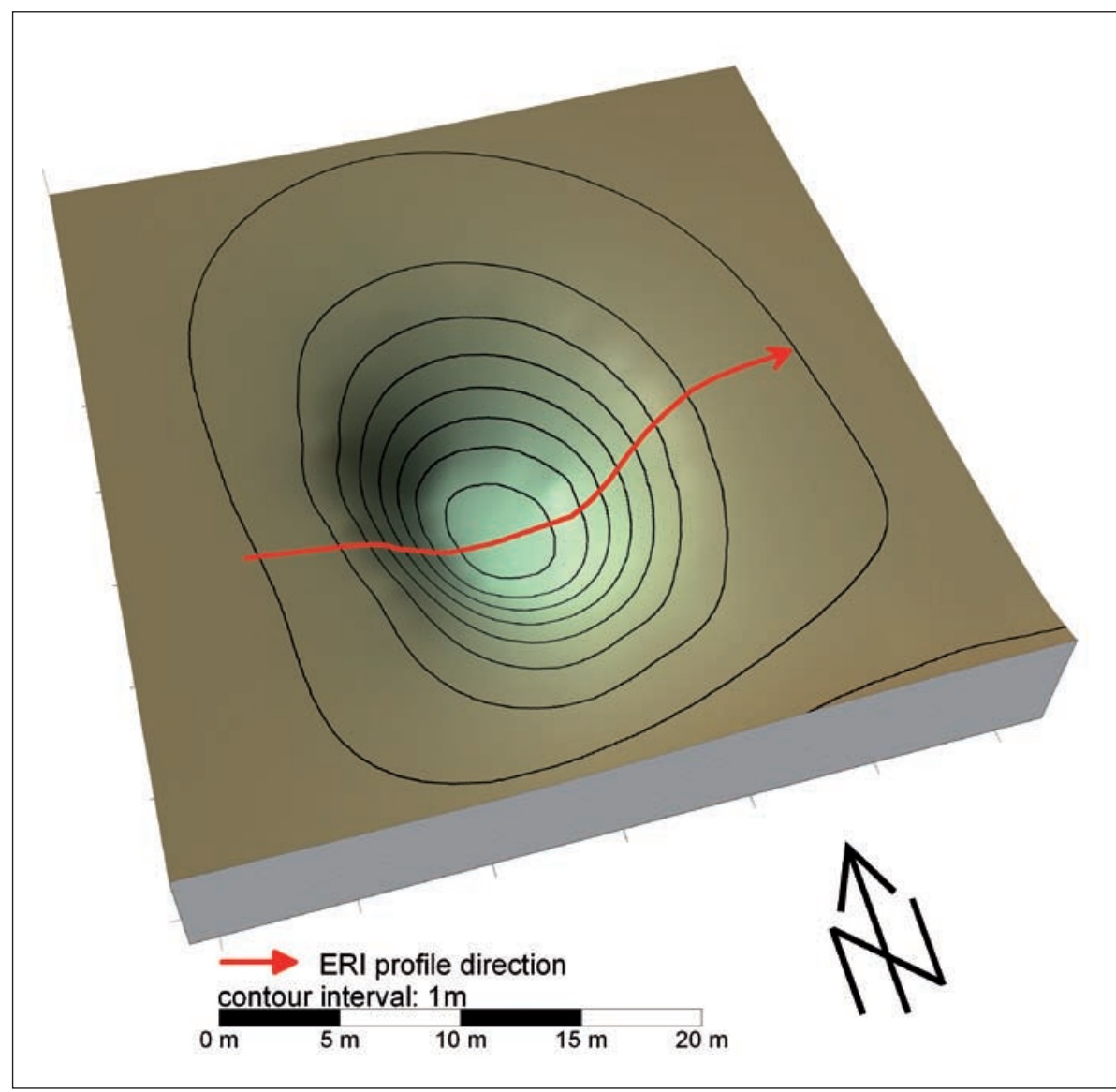

Fig. 3: DEM of the doline in dolomite in Begunjski ravnik area with the ERI profile direction.

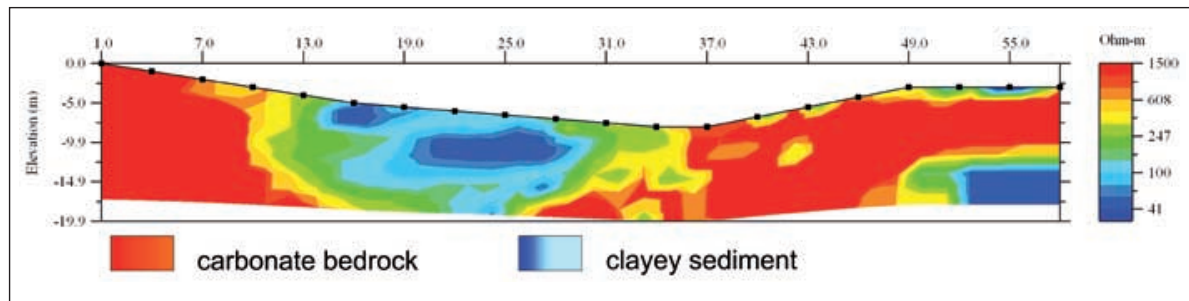

Fig. 4: ERI profile of the doline in limestone in Logaški ravnik area (ERI profile direction 286 degrees; RMS error $5.8 \%$ ).

Investigated doline is situated in the northern part of Logaški ravnik in Skalčen kamen area. The doline was defined by Jovan Cvijić (1893) as a typical example

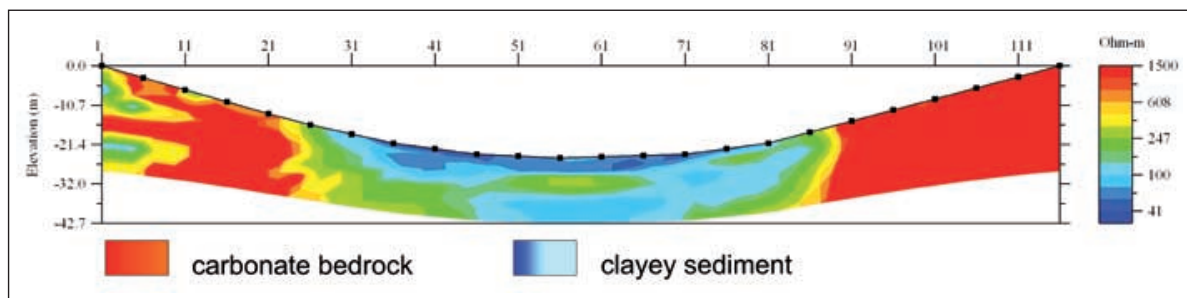

Fig. 6: ERI profile of the collapse doline in dolomite south of Kočevsko polje (ERI profile direction 97 degrees; $R M S$ error $2.72 \%$ ). of a solution doline in limestone. The doline is situated in Lower Jurassic compact limestone with dip of beds 35 degrees towards south west (Buser, 1963). The doline has longer diameter $40 \mathrm{~m}$, shorter diameter $35 \mathrm{~m}$ and depth $7 \mathrm{~m}$, approximate volume of the doline is $1600 \mathrm{~m}^{3}$. The slopes are covered with thin soil. Dip of the slopes of the doline are approximately 21 degrees with highest dip on western slope with 32 degrees where are bedrock outcrops. The floor of the doline is deepest in western part and covered with clayey soil.

Results of Electrical resistivity imaging with distance between two electrode pairs 3 metres shows, that inside the doline there is an extensive pocket of less resistant clayey material with resistivity value up to 250 ohm-m, which outcrops in eastern slope of the doline. Under the deepest part of the doline is limestone bedrock with some less resistant vertical structures with resistivity values between 250 and 1000 ohm-m which might function as rainwater and solution runoff. Other slopes of the doline are covered with thin layer of soil and weathered rock with resistivity values between up to $1000 \mathrm{ohm}-\mathrm{m}$ overlying limestone bedrock with resistivity value higher than $1000 \mathrm{ohm}-\mathrm{m}$.

\section{COLLAPSE DOLINE IN DOLOMITE SOUTH OF KOČEVSKO POLJE}

The area is situated in the southern part of Slovenia. South of Kočevsko polje is situated in levelled lowland in elevation of about $470 \mathrm{~m}$ - $490 \mathrm{~m}$. It consists mainly 


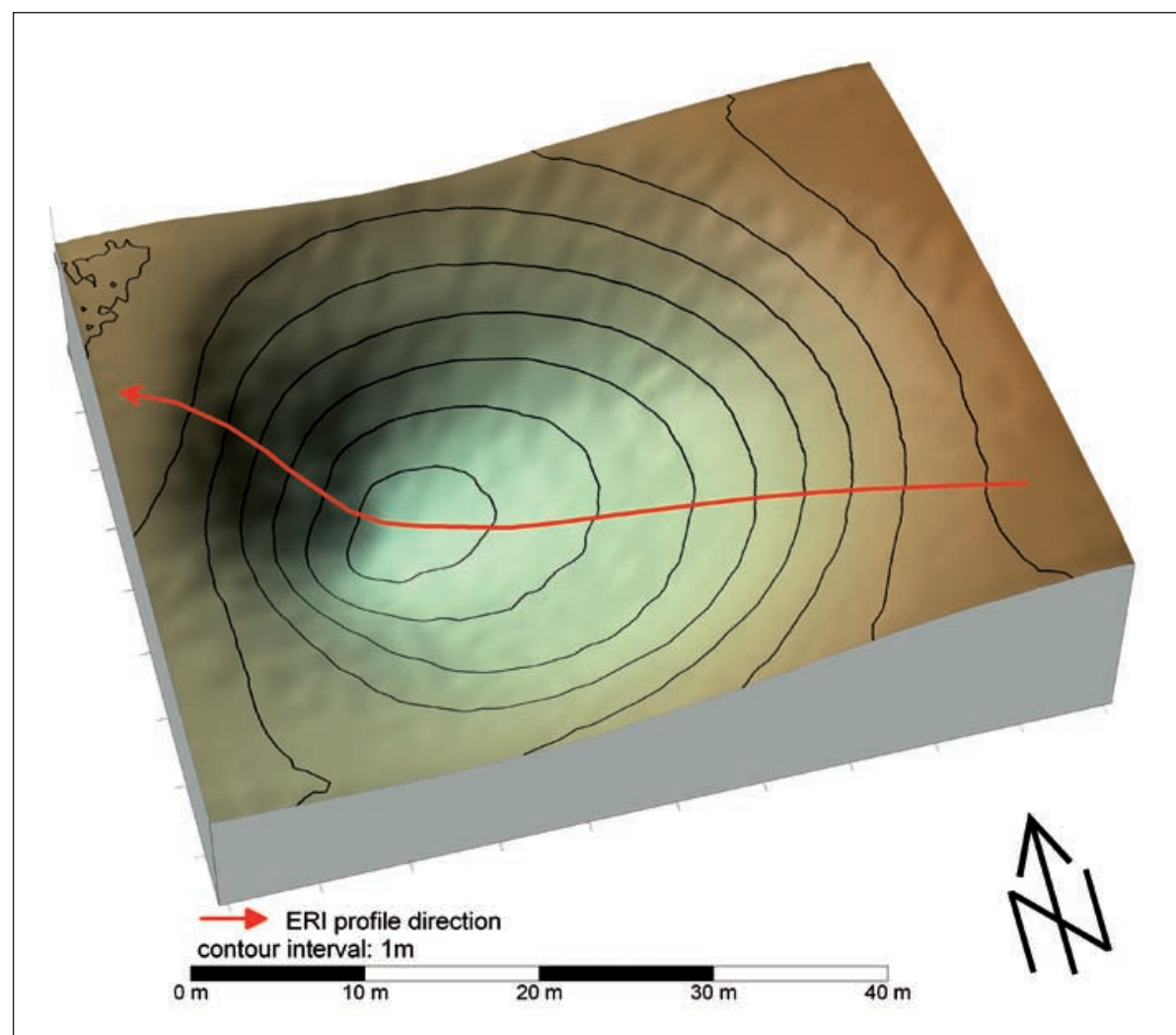

Fig. 5: DEM of the doline in limestone in Logaški ravnik area with the ERI profile direction.

Dozet, 1983). The direction of underground water flow is directed from ponors that are in elevation of $470 \mathrm{~m}$ in southern part of Kočevsko polje towards south to springs that are situated in the canyon of the Kolpa River (Habič, 1988) in elevation of $200 \mathrm{~m}$.

The collapse doline Globoka jama is $8 \mathrm{~km}$ southeast of Kočevje above underground water flow of the Rinža River. It is situated in upper Triassic dolomite with dip of beds 20 degrees toward south west (Savič, Dozet, 1983). The collapse doline has longer diameter $220 \mathrm{~m}$, shorter diameter $150 \mathrm{~m}$ and average depth of $33 \mathrm{~m}$, approximate volume of the collapse doline is $0.56 \mathrm{Mm}^{3}$. The slopes are covered with rocky soil. Dip of the slopes of the collapse doline is approximately 38 degrees with

of limestone and dolomite of Jurassic and Triassic age with dip of beds towards south and south west (Savič \&

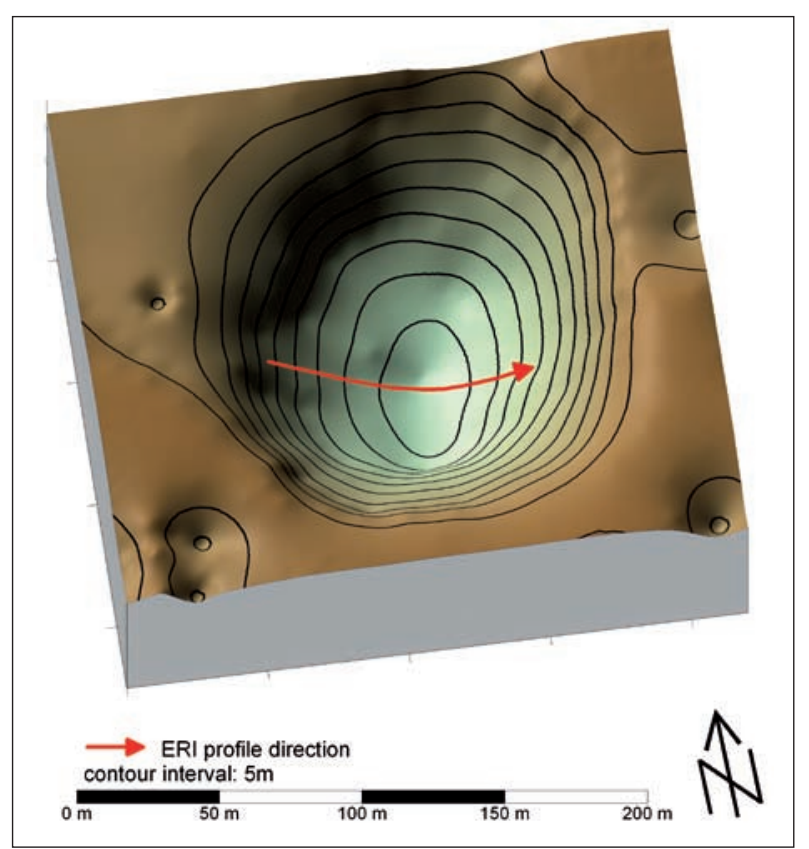

Fig. 7: DEM of the collapse doline in dolomite south of Kočevsko polje with the ERI profile direction. highest dip on western slope with 38 degrees where bedrock is exposed. The floor of the collapse doline is flat and covered with clayey soil.

Survey of the collapse doline with distance between two electrode pairs 5 metres revealed that bedrock slopes of the collapse dolines are covered with thin layer of less resistant soil and weathered rock with resistivity values up to $1000 \mathrm{ohm}-\mathrm{m}$. Thickness of weathered material is higher in the lower part of the slope. Floor of collapse doline is filled with clayey soil with resistivity values up to $250 \mathrm{ohm}-\mathrm{m}$. The depth of more conducting material in the floor of the collapse doline is more than 20 metres. Dolomite bedrock underlying slope material has resistivity value higher than $1000 \mathrm{ohm}-\mathrm{m}$.

\section{COLLAPSE DOLINE IN LIMESTONE IN RAKOV ŠKOCJAN AREA}

The area of Rakov Škocjan is situated between Cerkniško and Planinsko polje where the Rak river surface flow emerges. The area mainly consists of lower Cretaceous limestone with dip of beds between 10 to 30 degrees towards west (Buser 1963). Underground water flow is directed from Cerkniško polje towards NW to Planinsko polje (Habič, Gospodarič 1979; Kranjc 1996). 


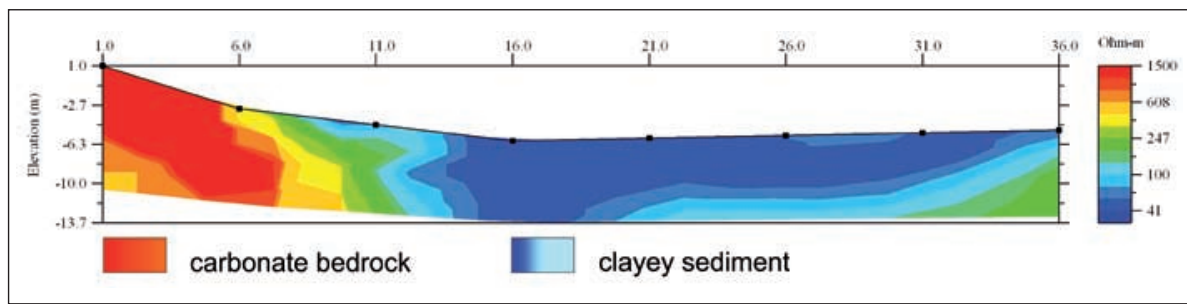

Fig. 8: ERI profile of the collapse doline in limestone in Rakov Škocjan area (ERI profile direction 254 degrees; RMS error $5.25 \%$ ).

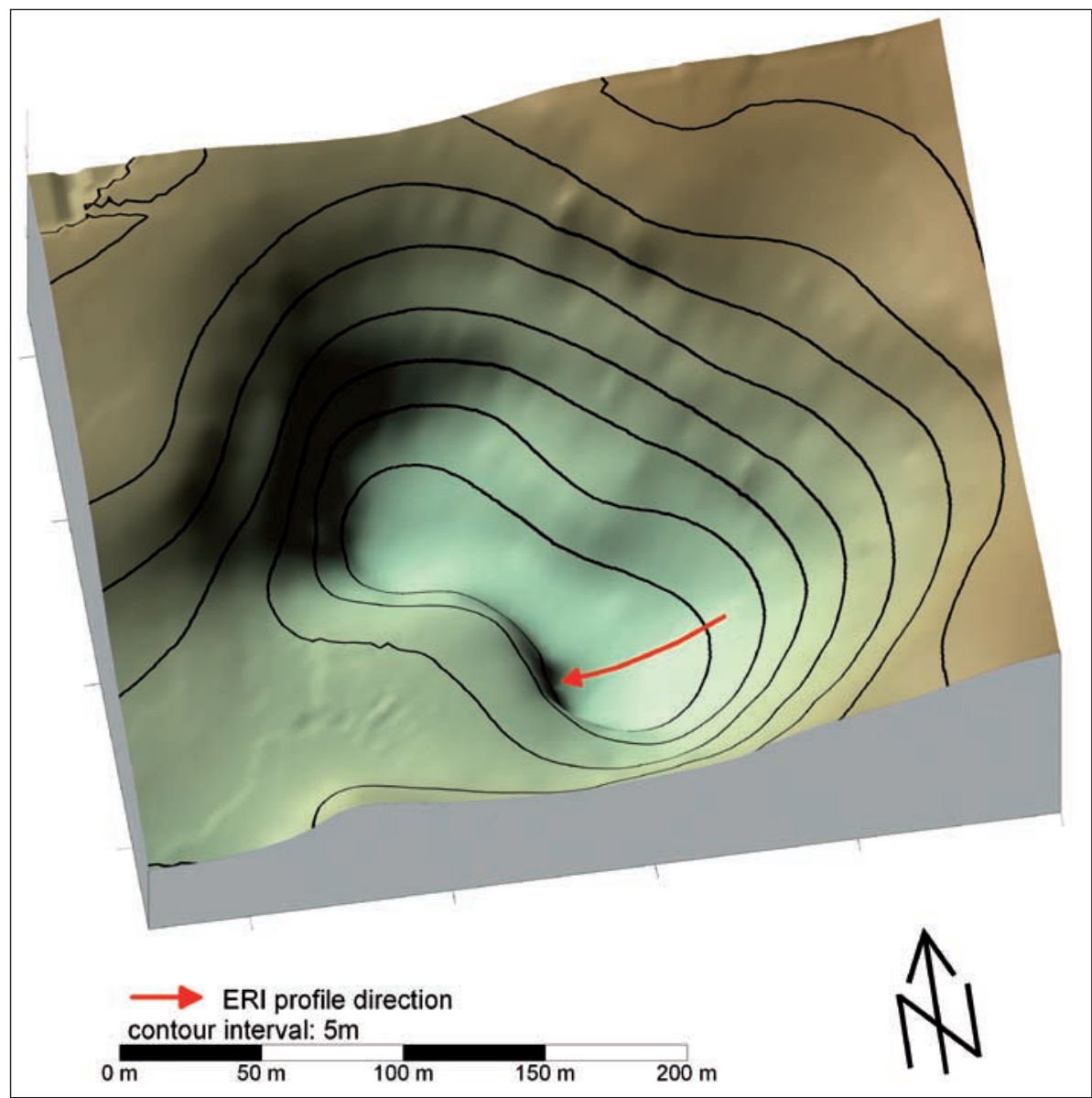

Fig. 9: DEM of the collapse doline in limestone in Rakov Škocjan area with the ERI profile direction.
In the eastern part of Rakov Škocjan area near to the entrance of cave system Zelške jame, collapse doline Globoščak (Dvojni Globoščak) is situated. The bedrock is lower Cretaceous well bedded limestone with dip of beds 25 degrees towards west (Buser 1963). The longer diameter of the collapse doline is $250 \mathrm{~m}$, shorter diameter is $150 \mathrm{~m}$ and average depth is $25 \mathrm{~m}$. Approximate volume of the doline is $0.4 \mathrm{Mm}^{3}$. Upper parts of the slopes are vertical rocky walls; lower parts of the slopes are covered with scree and rocky soil. Dip of the slopes covered with scree is approximately 30 degrees. The floor of the doline is flat and covered with clayey soil.

Survey was carried out with distance between two electrode pairs 5 metres. Resistivity values of limestone bedrock and scree on the slopes is more than 250 ohm-m. The floor of the collapse doline is filled with less resistant clayey sediment and weathered bedrock with thickness more than 10 metres. It has resistivity values below $250 \mathrm{ohm}-\mathrm{m}$. The thickness of clayey sediment filling the floor of collapse doline is more than 10 metres.

\section{CONCLUSIONS}

The profiles made with earth resistivity imaging clearly show the important differences of the analyzed dolines. They can be interpreted by other knowledge of the doline morphology and sediment profiles which were exposed in similar types of rock in quarries or road cuts.

Application of the method in collapse dolines and dolines in limestone and dolomite bedrock revealed sub- surface structure of this surface karst features. The application revealed that resistivity value for carbonate rock is more than $1000 \mathrm{ohm}-\mathrm{m}$, in a case of collapse doline in limestone bedrock the value is higher than $250 \mathrm{ohm}$ $\mathrm{m}$. For soil and weathered bedrock the resistivity values are between 250 and $1000 \mathrm{ohm}-\mathrm{m}$. Clayey material has resistivity values lower than $250 \mathrm{ohm}-\mathrm{m}$. In reality these 
threshold values may change spatially and temporally due to difference of subsurface structure and water content in bedrock and sediment. Some areas of high resistivity zones with resistivity values higher than $1000 \mathrm{ohm}$ $\mathrm{m}$ can be even subsurface open cave-like features. But data obtained by electrical resistivity imaging presented in this article corresponds with structures of various dolines that were revealed trough construction works on karst and with data obtained by investigation of collapse dolines on other parts of Slovenian karst (Stepišnik, 2006). Accuracy of subsurface images also decreases with higher distance between two electrode pairs therefore for smaller karst features distance between two electrode pairs should be smaller.

There is a clear difference between the smaller solution dolines and collapsed dolines. The results of ERI profiling in solution dolines show zones with important differences in electric properties of the rock. The bottoms of dolines show smaller resistivity. This can be explained as effect of retention of the water by sediment. There are no signs of empty spaces like shafts at the bottom and this both means that the bottoms of dolines are not favourable for vertical transport of sediments, even if there is a high vertical gradient in karst. On the slopes of these dolines there are zones where there is more resistant rock. There is no sediment and there are also some empty fissures as bedding planes and shafts possible, but they were not de- tected with this ERI survey. There are also small zones of less resistive rock, possibly cavities or fractured zones with clay or sediments containing some pore water.

The collapse dolines are defined as such because of much larger dimensions and we can explain their origin with the similar features that were evidently formed by transformation of underground cavities to surface depression and were later significantly modified by slope processes. In both collapse dolines we can clearly see the difference between slopes and bottoms. The slopes show highly resistive rock, that is limestone or scree without any finer sediment. At the bottom there are thick sediments and possibly collapse rubble mixed with fine grained sediments with larger water storage capacity. The origins of that sediment are not clear. There can be residual soils and clays washed to the bottom by slope processes or they are remnants of some cave infill that appeared at surface after or during the collapse dolines were formed.

The investigation presented in this article show that the method of Electrical resistivity imaging is useful for investigation of structure of various surface karst forms. But due to the lack of borehole data the presented ERI images are still one of many possible interpretations which roughly reflect subsurface structure of the surface karst features.

\section{REFERENCES}

Buser, S., 1963: Tolmač osnovne geološke karte za list Ribnica. Geološki zavod Ljubljana, pp. 68.

Cvijić, J., 1893: Das Karstphaenomen. Versuch einer morphologischen Monographie. Geogr. Abh. 5, 3, pp. 113.

EarthImager. 2003: 2D Resistivity and IP Inversion Software Instruction Manual. Version 1.2.0, Advanced Geosciences Inc. Austin.

Gabrovec, M., 1994: Relief in raba tal na dolomitnih območjih Slovenije. Doktorska disertacija, pp. 123.

Habič, P. \& Gospodarič R., 1979: Karst phenomena of Cerkniško polje. Acta carstologica 8, 1, 11-162.

Habič, P., 1985: Vodna gladina v notranjskem in primorskem krasu Slovenije. Acta carsologica, 13, 1, 37 -74 .

Habič, P., 1988: Tektonska pogojenost kraškega reliefa zahodne Suhe krajine. Acta carsologica, 17, str. 33 -64 .

Kataster jam JZS 2006. Jamarska zveza Slovenije.
Kranjc, A., 1986: Cerkniško jezero in njegove poplave. Geografski zbornik, 25, 75 - 123.

Loke, M. H., Barker, R. D., 1996: Rapid least-square inversion of apparent resistivity pseudosections by a quasi-Newton method. Geophys Prospect, 44, 131152.

Novak, D., 1993: Hydrogeological research of the Slovenian karst. Naše jame, 35, 1, 15-20.

Pleničar, M., 1963: Tolmač osnovne geološke karte za list Postojna. Geološki zavod Ljubljana, pp. 53.

Roman, I., 1951: Resistivity reconnaissance in American society of testing and materials - symposium on surface and subsurface reconnaissance. American society of testing materials special technical publication, 122, 121-226.

Savić, D., Dozet, S., 1983: Tolmač osnovne geološke karte za list Delnice. Geološki zavod Ljubljana, pp. 62. 
Stepišnik, U., 2006: Loamy sediment fills in collapse dolines near the Ljubljanica River springs, Dinaric karst, Slovenia. Cave and Karst Science, 33, 3, 105110.

Telford W. M., Geldart L. P., \& R. E. Sheriff, 1990: Applied geophysics (2. edition). New York, Cambridge University press.
Zhou, W., Beck, B. F. \& J. B. Stephenson, 2000: Reliability of dipole-dipole electrical resistivity tomography for defining depth to bedrock in covered karst terrains. Environmental Geology, 39, 760 - 766.

Zhou, W., Beck, B. F., Adams, A.C., 2002: Effective electrode array in maping karst hazards in electrical resistivity tomography. Environmental Geology, 42, $922-928$. 